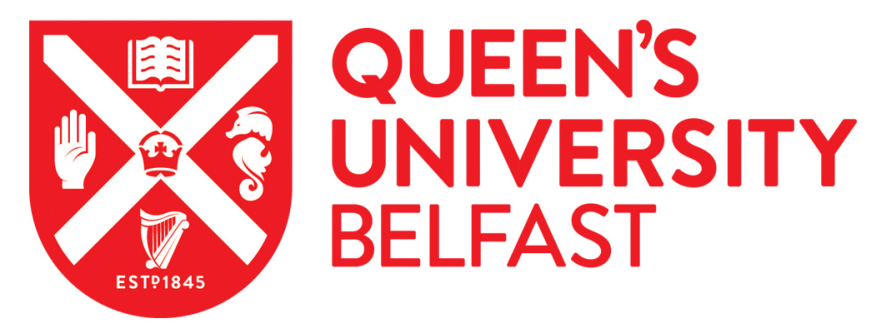

\title{
Circulating Leukocyte Alterations and the Development/Progression of Diabetic Retinopathy in Type 1 Diabetic Patients - A Pilot Study
}

Obasanmi, G., Lois, N., Armstrong, D., Lavery, N. J., Romero Hombrebueno, J. M., Lynch, A., Wright, D., Chen, M., \& Xu, H. (2020). Circulating Leukocyte Alterations and the Development/Progression of Diabetic Retinopathy in Type 1 Diabetic Patients - A Pilot Study. Current eye research.

https://doi.org/10.1080/02713683.2020.1718165

Published in:

Current eye research

Document Version:

Peer reviewed version

Queen's University Belfast - Research Portal:

Link to publication record in Queen's University Belfast Research Portal

Publisher rights

(C) 2020 Taylor \& Francis. This work is made available online in accordance with the publisher's policies. Please refer to any applicable terms of use of the publisher.

\section{General rights}

Copyright for the publications made accessible via the Queen's University Belfast Research Portal is retained by the author(s) and / or other copyright owners and it is a condition of accessing these publications that users recognise and abide by the legal requirements associated with these rights.

Take down policy

The Research Portal is Queen's institutional repository that provides access to Queen's research output. Every effort has been made to ensure that content in the Research Portal does not infringe any person's rights, or applicable UK laws. If you discover content in the Research Portal that you believe breaches copyright or violates any law, please contact openaccess@qub.ac.uk. 
- Manuscript publication in Current Eye Research on $30^{\text {th }}$ Jan 2020

doi.org/10.1080/02713683.2020.1718165

Circulating leukocyte alterations and the development/progression of diabetic retinopathy in type 1 diabetic patients - a pilot study

Gideon Obasanmi ${ }^{1}$, Noemi Lois $^{1}$, David Armstrong ${ }^{1}$, Nuala-Jane Lavery ${ }^{1}$, Jose Romero Hombrebueno $^{1}$, Aisling Lynch ${ }^{1}$, David M. Wright ${ }^{2}$, Mei Chen ${ }^{1}$, Heping Xu ${ }^{1 *}$ Institutional Address:

${ }^{1}$ Wellcome-Wolfson Institute for Experimental Medicine, School of Medicine, Dentistry and Biomedical Sciences, Queen's University Belfast, Belfast, United Kingdom

${ }^{2}$ Centre for Public Health, School of Medicine, Dentistry and Biomedical Sciences, Queen's University Belfast, Belfast, United Kingdom

Email: GO: gobasanmi01@qub.ac.uk; NL: n.lois@qub.ac.uk; DA:

david.armstrong@belfasttrust.hscni.net; NJL: nualajane.lavery@belfasttrust.hscni.net; JRH:

j.romero@qub.ac.uk; AL: aislinglynch86@hotmail.com; DMW: d.wright@qub.ac.uk; MC:

$\underline{\text { m.chen@qub.ac.uk; HX: heping.xu@qub.ac.uk }}$

Running title: Circulating immune cells in DR

*, Correspondence to Heping $\mathrm{Xu}$, Wellcome-Wolfson Institute for Experimental Medicine, Queen's University Belfast, 97 Lisburn Road, BT9 7BL, Belfast, UK. Tel: +44 2890976463 , email: heping.xu@qub.ac.uk

Word Count: 3270 
- Manuscript publication in Current Eye Research on $30^{\text {th }}$ Jan 2020 doi.org/10.1080/02713683.2020.1718165

\section{ABSTRACT}

Background/Aims: The aim of this study was to investigate the relationship between alterations in circulating leukocytes and the initiation and progression of DR in people with type 1 diabetes (T1D).

Methods: Forty-one patients with T1D [13 mild non-proliferative DR (mNPDR), 14 active proliferative DR (aPDR) and 14 inactive PDR (iPDR)], and 13 age- and gender-matched healthy controls were recruited prospectively. Circulating leukocytes, including $\mathrm{CD}^{+}$and $\mathrm{CD} 8^{+} \mathrm{T}$-cells, $\mathrm{CD}^{+} 4^{+} \mathrm{CD} 16^{-}, \mathrm{CD} 14^{-\mathrm{CD}} 16^{+}$and $\mathrm{CD} 14^{+} \mathrm{CD} 16^{+}$monocytes; CD16 ${ }^{+} \mathrm{HLA}-\mathrm{DR}{ }^{-}$neutrophils, $\mathrm{CD} 19^{+}$ B-cells and $\mathrm{CD}^{+} 6^{+}$natural killer cells and their cell surface adhesion molecules and chemokine receptors (HLA-DR, CD62L, CCR2, CCR5, CD66a, CD157 and CD305) were examined by flow cytometry.

Results: In DR patients, compared to healthy controls, increased proportions of neutrophils $(p=0.0152)$; reduced proportions of lymphocytes $(p=0.0002)$, HLA-DR ${ }^{+}$leukocytes $(p=0.0406)$ and non-classical monocytes $(p=0.0204)$; and reduced expression of CD66a $(p=0.0048)$ and CD157 ( $p=0.0007)$ on $\mathrm{CD}^{+} \mathrm{T}$ cells were observed. Compared to healthy controls, $\mathrm{CD} 19^{+} \mathrm{B}$ cells were reduced at the mNPDR but not aPDR patients. Total lymphocytes, $\mathrm{CD} 4^{+} \mathrm{T}$ cells and $\mathrm{CD} 8^{+}$ $\mathrm{T}$ cells progressively decreased whereas neutrophils, the neutrophil/lymphocyte ratio and the neutrophil/CD4 ${ }^{+}$ratio progressively increased from early to late stages of DR, reaching statistical significance at the aPDR stage. Longer diabetes duration was associated with a reduced proportion of $\mathrm{CD}^{+} \mathrm{T}$ cells $(p=0.002)$ and increased neutrophil/CD8 ${ }^{+}$ratio $(p=0.033)$.

Conclusions: In this pilot study, DR is associated with increased innate cellular immunity especially neutrophils and reduced adaptive cellular immunity particularly lymphocytes. Impaired B-cell immunity may play a role in the initiation of DR; whereas impaired T-cell immunity with increased neutrophil response may contribute to progression of DR from non-proliferative to 
- Manuscript publication in Current Eye Research on $30^{\text {th }}$ Jan 2020 doi.org/10.1080/02713683.2020.1718165

proliferative stages in T1D patients. Large multicenter studies are needed to further understand the immune dysregulation in DR initiation and progression.

Keywords: type 1 diabetes, diabetic retinopathy, neutrophils, lymphocytes, flow cytometry

Short Running Head: Circulating Leukocytes in Diabetic Retinopathy 
- Manuscript publication in Current Eye Research on $30^{\text {th }}$ Jan 2020 doi.org/10.1080/02713683.2020.1718165

\section{BACKGROUND}

Diabetic retinopathy (DR) is the progressive degeneration of retinal microvasculature resulting from diabetes, and is a leading cause of blindness in the global working population. ${ }^{1}$ Pathologically, DR often progresses through microvascular degeneration, ischemia to neovascularisation stages. Clinically, patients may experience mild non-proliferative DR (NPDR) at the early stage, to moderate NPDR and then to severe NPDR. ${ }^{2}$ Some patients will then go into developing the vision-threatening form of DR known as proliferative DR (PDR), which, if untreated, will lead to blindness. ${ }^{1,2}$

Inflammation has been recognized to play a major role in the pathophysiology of DR, from the early to late stages of the disease, ${ }^{3}$ although the underlying mechanisms remain largely unclear. Systemic biochemical malfunction, oxidative stress, formation and accumulation of advanced glycation end-products (AGEs) and the hyperglycemic microenvironment in diabetes, all promotes noxious stress. ${ }^{3}$ This stressful microenvironment elevates low-grade cellular activation and inflammation (parainflammation) which can be prolonged to sustain a DR disease-state. ${ }^{4}$

The complex relationship between retinal microvasculature and the immune system involves the two immune subsystems, innate and adaptive, which often collaborate to eliminate exogenous and endogenous threats to restore homeostasis. Evidence is accumulating about the possible contribution of the innate immune system towards the pathogenesis of DR. ${ }^{5}$ In contrast, little is known of the role of the adaptive immune system in the initiation and progression of DR.

Immune cells are key players in inflammation. In DR, when the blood-retinal barrier (BRB) breaks down, circulating immune cells, infiltrate the retina causing inflammation. ${ }^{6}$ The activation of microglia ${ }^{7}$ and leukostasis, ${ }^{8}$ the latter a phenomenon of immune cell adherence to, and entrapment in retinal blood vessels, are hallmarks of DR-related inflammation. 
- Manuscript publication in Current Eye Research on $30^{\text {th }}$ Jan 2020 doi.org/10.1080/02713683.2020.1718165

Type-1 diabetes (T1D) is an autoimmune disease. Therefore, malfunction of the immune system plays an important role in its pathogenesis and pathophysiology. ${ }^{9}$ In T1D without DR, reported pathological changes in systemic parameters include modifications in cell counts and functions of circulating neutrophils, monocytes and lymphocytes. ${ }^{10-12}$ Many studies have investigated the contribution of local retinal inflammation to DR including leukostasis, microglial activation, vascular leakage and neovascularization. ${ }^{3,7}$ However, the contributions of systemic inflammation and alteration of circulating leukocyte profiles to DR initiation and progression, from non-proliferative to proliferative stages, has not been investigated.

In PDR, new abnormal blood vessels grow on the surface of the optic nerve and retina, often leading to intraocular bleeding (vitreous hemorrhage) and sight loss. Furthermore, because of development and contraction of fibrovascular membranes, tractional retinal detachment can also ensue with often irreparable effects on vision. For many years, PDR was treated with panretinal photocoagulation (PRP), which remains today as the most widely used PDR therapy. ${ }^{13}$ It is known that, following treatment, PDR remains inactive in many patients, however, in others, the disease may reactivate. The reasons for this reactivation remain obscure. The immunophenotype of inactive proliferative DR (iPDR) versus active PDR (aPDR) has not been investigated and it could be hypothesized that aspects of patients' immune system may explain, at least partly, this reactivation.

Duration of diabetes is an established risk factor for DR and one of the strongest predictors of DR initiation and progression. ${ }^{14}$ However, the relationship between diabetes duration and changes in circulating immune cells has not been investigated in the context of T1D DR. Overall, there is a growing need to capture and report the systemic immune signatures of T1D DR and its different stages with a view towards uncovering novel targets for therapy. 
- Manuscript publication in Current Eye Research on $30^{\text {th }}$ Jan 2020 doi.org/10.1080/02713683.2020.1718165

The purpose of this small cohort case control study was to investigate whether systemic alterations in the populations of major circulating immune cells of innate and adaptive immunity (including neutrophils, monocytes and lymphocytes) and their expression of inflammatory, activation and cell adhesion markers in T1D patients with DR could be associated with onset and progression of DR. The effect of duration of diabetes on levels of circulating leukocyte populations in T1D DR patients was also studied.

\section{SUBJECTS AND METHODS}

\section{Study Participants}

The study protocol was approved by the Office for Research Ethics Committees Northern Ireland (ORECNI, Ref: 14/NI/0084) and procedures were performed in accordance with the tenets of the Declaration of Helsinki on research into human volunteers. Written informed consent was obtained from all participants prior to their enrolment in this study. A study identification number was assigned to each participant and used throughout the study to maintain participant confidentiality.

This study was designed as a pilot cross sectional study of T1D patients. Participants were eligible if they met the following inclusion and exclusion criteria. Inclusion criteria: Age $\geq 18$, diagnosis of T1D and presence of NPDR or PDR. Exclusion criteria: Lack of DR; history of severe cardiac diseases, malignancy within the past 5 years and; infectious/non-infectious inflammatory diseases within 2 months; presence of active autoimmune disease; history or concurrent use of immunosuppressive medications or steroids; pregnancy; kidney failure; presence of other eye conditions that may affect DR diagnosis; any conditions that could prevent/affect the quality of DR evaluation and retinal imaging (e.g. marked media opacities).

The following information was collected prospectively for each participant: gender, age, duration of T1D, family history of T1D, systolic BP, diastolic BP, BMI, smoking history, age at 
- Manuscript publication in Current Eye Research on $30^{\text {th }}$ Jan 2020

doi.org/10.1080/02713683.2020.1718165

T1D diagnosis, duration of insulin, presence of other diabetic complications, history of macrovascular disease, history of hypertension and duration of hypertension. All patients underwent a full ophthalmic examination, including detailed slit-lamp biomicroscopy and grading of their DR.

T1D patients $(n=41)$ were sub-grouped into one of three DR groups: (1) mild NPDR (mNPDR, n=13); (2) untreated active PDR (aPDR; n=14) and (3) treated inactive PDR (iPDR; $n=14)$. A healthy control group of participants $(n=13)$ that was age- and gender-matched with T1D patients was also recruited. Written informed consent was also obtained for this group prior to participation in the study. Healthy controls had no diabetes and no known eye diseases (mild cataracts were allowed).

\section{Masking}

Investigators who carried out laboratory assays and data analyses were masked to the clinical status of study participants.

\section{Blood Collection}

Peripheral blood samples $(20 \mathrm{~mL})$ were drawn into tubes containing ethylenediaminetetraacetic acid (EDTA; BD Biosciences, Oxford, UK) and processed within 3h of collection.

\section{The following tests were then conducted in blood samples:}

\section{Peripheral Whole Blood Flow Cytometry Staining}

$30 \mu \mathrm{L}$ of freshly drawn whole blood from study participants was incubated with fluorochromelabelled antibodies (Table 1) in FACS buffer (1\% FCS in PBS) for 45 minutes at $4{ }^{\circ} \mathrm{C}$ in the dark. After washing twice with FACS buffer, samples were incubated with $2 \mathrm{~mL}$ of $1 \mathrm{X}$ red blood cell lysis buffer (BD Biosciences, Oxford, $\mathrm{UK}$ ) for 10min at room temperature to eliminate all red blood cells. Cells were then thoroughly washed with FACS buffer before fixing in $2 \%$ 
- Manuscript publication in Current Eye Research on $30^{\text {th }}$ Jan 2020

doi.org/10.1080/02713683.2020.1718165

paraformaldehyde (PFA) for $30 \mathrm{~min}$ in the dark at $4^{\circ} \mathrm{C}$. Cells were again thoroughly washed twice and then acquired on a BD Canto II flow cytometer (BD Biosciences, San Jose, CA, USA). 10,000 live cells were acquired on the flow cytometer for all experiments. Post-acquisition analysis of flow-cytometry data was performed with FlowJo version 10 (Tree Star, Inc., Ashland, OR, USA).

\section{Flow Cytometry Analyses}

Gating strategies used in this study are summarized in Figure 1. The neutrophil-lymphocyte ratio (NLR) was calculated by dividing the percentage of neutrophils by the percentage of all lymphocytes; other cell ratios presented herein including the lymphocyte-monocyte ratio (LMR) were calculated in a similar manner.

\section{Statistical Analyses}

All continuous variables were tested for normal distribution using the D'Agostino-Pearson omnibus normality test. These variables were then expressed as the mean and standard error of the mean (SEM). Two group comparisons were carried out using Student's t-test for independent samples. Tests with $p<0.05$ were considered statistically significant. Comparison among more than two groups was carried out using one-way analysis of variance (ANOVA) followed by Tukey's multiple comparisons post-hoc test. These tests were made using Graphpad Prism 6 (Graphpad, San Diego, CA, USA). Univariable analyses of demographic factors, linear regression and correlation of duration of diabetes vs biomarkers were carried out using Statistical Package for the Social Sciences, Windows version 24 (SPSS; SPSS Inc, Armonk, NY, USA). 
- Manuscript publication in Current Eye Research on $30^{\text {th }}$ Jan 2020

doi.org/10.1080/02713683.2020.1718165

\section{RESULTS}

\section{Characteristics of Study Participants}

No statistically significant differences between DR patients and healthy controls in age, gender distribution, duration of T1D, family history of T1D, systolic blood pressure (BP), diastolic BP, body mass index (BMI), smoking history, age at T1D diagnosis, duration of insulin, presence of other diabetic complications, proportion with history of macrovascular disease, proportion with history of hypertension and duration of hypertension (Table 2).

\section{Increased neutrophils in patients with T1D and DR}

DR patients compared to healthy controls showed a statistically significantly increased proportion of CD16 ${ }^{\text {hi } H L A-D R}{ }^{-}$leukocytes (neutrophils; Figure $2 A ; p=0.0152$ ). In contrast, the proportion of HLA-DR $^{+}$leukocytes were statistically significantly reduced (Figure 2B; $p=0.0406$ ). The proportion of non-classical monocytes $\left(\mathrm{CD} 14^{-} \mathrm{CD} 16^{+}\right)$in the overall monocyte population was also significantly reduced in DR patients compared to healthy controls (Figure $2 \mathbf{2} ; p=0.0204$ ). There were no significant differences between DR and controls in other innate immunity parameters, including $\mathrm{CD}^{+} 6^{+}$(Natural killer cells; Figure 2C; $p=0.5078$ ), total monocytes (Figure 2D; $p=0.7017)$, classical monocytes $\left(\mathrm{CD} 14^{+} \mathrm{CD} 16^{-}\right.$; Figure $\left.2 \mathrm{~F} ; p=0.7144\right)$, intermediate monocytes $\left(\mathrm{CD} 14^{+} \mathrm{CD} 16^{+} ;\right.$Figure 2G; $\left.p=0.8796\right), \mathrm{CCR} 2$ (Figures 2H $[p=0.2532]$ and $\left.\mathbf{2 I}[p=0.2991]\right), \mathrm{CCR} 5$ (Figures 2J $[p=0.1083]$ and $\mathbf{2 K}[p=0.3898])$; and CD62L (Figures 2L [ $p=0.6656]$ and 2M $[p=0.6352])$.

\section{Reduced lymphocytes in T1D DR}

Compared with healthy controls, the DR patients exhibited a statistically significantly lower proportion of circulating lymphocytes (Figure 3A; $p=0.0002$ ), including $\mathrm{CD}^{+} \mathrm{T}$ cells (Figure 3B; $p=0.0018), \mathrm{CD}^{+} \mathrm{T}$ cells (Figure 3C; $\left.p=0.0275\right)$ and $\mathrm{CD} 19^{+} \mathrm{B}$ cells (Figure 3D; $p=0.0003$ ). 
- Manuscript publication in Current Eye Research on $30^{\text {th }}$ Jan 2020

doi.org/10.1080/02713683.2020.1718165

The expression of CD66a or carcinoembryonic antigen-related cell adhesion molecule 1 (CEACAM1) and CD157 or bone marrow stromal cell antigen 1 (BST1) on CD4 ${ }^{+}$T cells was also statistically significantly reduced in DR patients compared to healthy controls (Figures $\mathbf{3 E}$ $[p=0.0048]$ and 3F $[p=0.0007])$. No statistically significant difference in CD305 or leukocyteassociated Ig-like receptor-1 (LAIR-1) expression on $\mathrm{CD}^{+} \mathrm{T}$ cells were found between DR patients and healthy controls (Figure 3G; $p=0.9842$ ).

\section{Increased neutrophil/lymphocyte ratios in T1D DR}

DR patients had a statistically significantly higher neutrophil-lymphocyte ratio (NLR; Figure 4A;

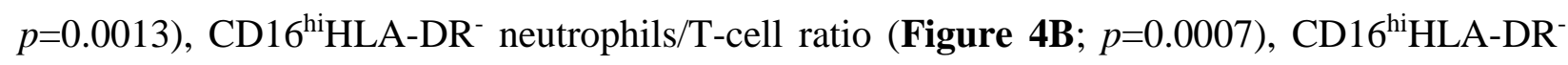

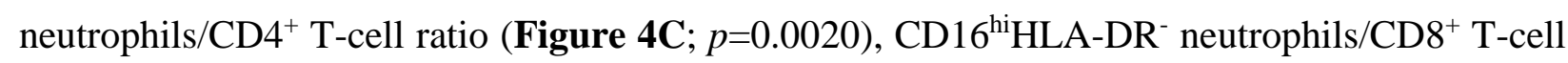
ratio (Figure 4D; $p=0.0109$ ) and $\mathrm{CD}_{16}{ }^{\mathrm{hi}} \mathrm{HLA}_{-\mathrm{DR}}{ }^{-}$neutrophils/CD19 ${ }^{+}$B-cell ratio (Figure 4E; $p=0.0002$ ) than age-matched healthy controls and a statistically significantly lower lymphocytemonocyte ratio (LMR; Figure 4G; $p=0.0273$ ) and T-cell/CD14 ${ }^{+}$ratio (Figure 4H; $p=0.0283$ ). No statistically significant differences were found in CD16 ${ }^{\text {hi }} \mathrm{HLA}_{-} \mathrm{DR}^{-}$neutrophils/monocyte ratio between DR patients and healthy controls (Figure 4F; $p=0.1431$ ).

\section{T1D duration is associated with altered immunophenotype}

Statistically significant negative associations were detected between diabetes duration and (1) the percentage of $\mathrm{CD}^{+} \mathrm{T}$ cells, and (2) $\mathrm{T}$-cell/CD14 ${ }^{+}$ratio (Figures 5A, B). Statistically significant positive associations were found between diabetes duration and (1) CD16 ${ }^{\text {hi HLA-DR }}{ }^{-}$ neutrophils/T-cell ratio, (2) CD16 ${ }^{\text {hiHLA-DR }}{ }^{-}$neutrophils/CD4 ${ }^{+}$T-cell ratio, and (3) CD16 ${ }^{\text {hi HLA- }}$ $\mathrm{DR}^{-}$neutrophils/CD8 ${ }^{+} \mathrm{T}$-cell ratio (Figures 5C-E). No other statistically significant associations 
- Manuscript publication in Current Eye Research on $30^{\text {th }}$ Jan 2020

doi.org/10.1080/02713683.2020.1718165

between diabetes duration and other biomarkers including CD16 ${ }^{\text {hi HLA-DR }}{ }^{-}$neutrophils, total lymphocytes, CD4 ${ }^{+} \mathrm{T}$ cells and $\mathrm{CD} 19^{+} \mathrm{B}$ cells were found (Figures 5F-I).

\section{Alteration in innate and adaptive immunity in early and late DR}

To investigate the potential contribution of circulating immune cells to DR initiation and progression, patients were sub-grouped into mild NPDR (mNPDR), active PDR (aPDR) and inactive PDR (iPDR). The population of total lymphocytes, $\mathrm{CD} 4^{+} \mathrm{T}$ cells and $\mathrm{CD} 8^{+} \mathrm{T}$ cells progressively decreased from healthy controls, mNPDR to aPDR reaching statistical significance at the aPDR stage (Figures 6A-C); whereas the population of $\mathrm{CD} 19^{+} \mathrm{B}$ cells was significantly reduced at the early stage of DR i.e. mNPDR but with no further reduction among aPDR patients (Figure 6D). In contrast, the population of neutrophils, the neutrophil/lymphocyte ratio and the neutrophil/CD4 ${ }^{+}$T-cell ratio progressively increased from early to late stages of DR reaching statistical significance at the aPDR stage (Figures 6E-G). There were no statistically significant differences in any immune cell parameters between aPDR and iPDR patients (Figures 6A-G).

\section{DISCUSSION}

The results from this study suggest that DR is associated with an increased neutrophil-driven inflammatory response and a concomitantly diminished lymphocyte-driven immunocompetence. Data suggests a reduced level of CD19+ B cells may be implicated in the development of DR, whereas reduced $\mathrm{CD} 4^{+}, \mathrm{CD}^{+} \mathrm{T}$ cells and increased neutrophils may play a role in progression from the non-proliferative to the proliferative, more advanced stage of the disease.

Clinical features of mNPDR include microaneurysms, microhemorrhages, exudates and localized vascular leakage. ${ }^{6,15}$ Retinal capillary walls are composed of endothelial cells, basement membrane and pericytes. ${ }^{16}$ Microaneurysms are dilated vessels, likely result of endothelial and 
- Manuscript publication in Current Eye Research on $30^{\text {th }}$ Jan 2020 doi.org/10.1080/02713683.2020.1718165

pericyte cell deaths. Increased leukostasis is known to contribute to endothelial cell (EC) death in DR. ${ }^{17}$ Previous studies have shown that myeloid-derived cells, in particular, neutrophils are the main cell types that cause leukostasis. ${ }^{8,18}$ Although the population of neutrophils was increased in mNPDR patients relative to healthy controls, differences were only statistically significant at the aPDR stage, suggesting that neutrophils may play a more prominent role in advanced stages of disease and possibly in DR progression from the non-proliferative to the proliferative stages. Previous studies showed that antibodies can induce pericyte damage through activation of the complement pathway, which may contribute to the pathogenesis of DR. ${ }^{19,20} \mathrm{~B}$ cell function is regulated by CD4 T helper cells. Our data suggests that dysregulated B-cell immunity may play a role in the development of DR. Further studies on the link between reduced B-cell populations and pericyte loss would help to understand how dysregulated B-cell immunity could contribute to the development of DR in T1D patients.

It is thought that progression of DR from mNPDR to aPDR is driven by severe ischemia, which results from extensive retinal vascular degeneration, with the subsequent release of growth factors, including vascular endothelial growth factor (VEGF) which would lead, on its turn, to new blood vessels formation. Chronic inflammation is known to contribute towards both retinal vascular/neuronal degeneration and angiogenesis. ${ }^{3}$ The progressive increase in systemic neutrophils may lead to an increased number of neutrophils in the retina during the course of DR causing continued damage to retinal vasculature through leukostasis. Neutrophils also play an important role in pathogenic angiogenesis. ${ }^{21,22}$ Whether increased number of circulating neutrophils could be directly related to the outgrowth of blood vessels in PDR and whether it could be used as a predictive biomarker of risk warrant further investigation.

Neutrophils are the frontline effector cells of the innate immune system that defend the body against pathogens; nevertheless, precise control of circulating neutrophil populations is essential to balance effective resistance and immunosuppression or inflammation. ${ }^{23}$ Elevated 
- Manuscript publication in Current Eye Research on $30^{\text {th }}$ Jan 2020 doi.org/10.1080/02713683.2020.1718165

neutrophils in diabetes is reported to occur as a result of increased granulocyte colony-stimulating factor (G-CSF) in plasma of T1D patients. ${ }^{24}$ Nagareddy et al. ${ }^{24}$ showed that elevated innate leukocytes in diabetes is due to diabetes-driven proliferation of bone marrow myeloid progenitors, releasing elevated proportions of innate myeloid cells, particularly neutrophils into the circulation.

Circulating $\mathrm{T}$ cells, including $\mathrm{CD} 4^{+}$and $\mathrm{CD}^{+} \mathrm{T}$ cells were more markedly reduced in the advanced stages of disease (aPDR) than in early stages (mild NPDR) in this study. These findings suggest a link between reduced T-cell immunity and progression of DR from non-proliferative to proliferative stages although the underlying mechanisms remain elusive. Compromised T-cell immunity may initiate a non-resolving, low-grade inflammatory response which may further contribute to DR pathophysiology. ${ }^{25}$ Perhaps, the reduced adaptive cellular immunity observed in the current study may explain, at least partly, why diabetic patients are generally more susceptible to developing frequent and protracted bacterial and fungal infections, some of which are fatal. ${ }^{26,27}$ It is accepted that non-classical monocytes can become dendritic cells with greater competence of inducing T-cell proliferation. ${ }^{28}$ The observation of reduced non-classical monocytes herein may relate to the reduced populations of T cells in T1D DR.

The reduction in HLA-DR ${ }^{+}$leukocyte proportions may be central to the key changes in lymphocyte populations observed in this study and may contribute to DR pathology via diminished antigen presentation and consequently, diminished ability to resist diseases. ${ }^{29,30}$ HLA-DR is a major histocompatibility complex, class II (MHC-II) molecule primarily expressed on antigen presenting cells (APCs) including dendritic cells and monocytes and is an important player in many autoimmune diseases. ${ }^{29,30}$ It primarily functions to present peptide antigens by APCs to the T-cell receptor (TCR) of T-helper cell to elicit responses that eventually lead to antibody production and T-helper cell activation and proliferation. Reduced HLA-DR in DR patients suggests a reduced capacity of APCs to present antigens, hence less T-cell activation and proliferation, and B-cell maturation. 
- Manuscript publication in Current Eye Research on $30^{\text {th }}$ Jan 2020 doi.org/10.1080/02713683.2020.1718165

CD66a is a regulator of immune responses. T-cell activation and tolerance can be regulated via the expression of cell surface inhibitory receptors including CD28-related molecules and nonCD28-related molecules such as CD66a. ${ }^{31}$ Blocking, inactivating or deleting CD66a is associated with hyperactivation of T-cells, ${ }^{31}$ resulting in an autoimmune disease state and worsening of both systemic glucose intolerance and hepatic insulin resistance. ${ }^{32} \mathrm{CD} 66 \mathrm{a}$ also regulates angiogenesis, vascular permeability and retinal neovascularization. ${ }^{33}$ The expression of CD66a on $\mathrm{CD}^{+}{ }^{+}$cells was reduced in the T1D patient cohort in the current study, which may contribute to DR pathology via dysregulated T-cell activation. CD157 is mainly known to support B-cell survival and regulate chemotaxis in neutrophils. ${ }^{34}$ Perhaps the importance of CD157 to B-cell survival and antibody production $^{35}$ may partially explain the significant reduction of systemic proportions of CD19+ $\mathrm{B}$ cells in DR observed herein.

Taken together, the progressive increase of neutrophils and reduction of T cells, as well as the dysregulated T-cell activation in T1D may result in uncontrolled chronic inflammation in the diabetic retina, contributing to the progression of the disease from non-proliferative to proliferative stages.

The current study suggests that lower $\mathrm{CD}_{19}{ }^{+} \mathrm{B}$ cells could be potentially used as biomarkers of risk of DR development while reduced total lymphocytes, $\mathrm{CD} 4^{+} \mathrm{T}$ cells and $\mathrm{CD} 8^{+}$ T cells; and increased neutrophils, NLR and neutrophil/CD4 ${ }^{+}$T-cell ratio could be potentially used as biomarkers of DR progression from mNPDR to aPDR. Prospective longitudinal studies are warranted to further investigate the prognostic and predictive significance of these biomarkers in DR.

Data suggests that diabetes duration is an independent explanatory variable that has significant associations with altered immune cell proportions and ratios in patients with T1D DR, with increasing inflammatory immunophenotype and immunodeficiency as T1D duration 
- Manuscript publication in Current Eye Research on $30^{\text {th }}$ Jan 2020 doi.org/10.1080/02713683.2020.1718165

increases. These associations are important especially for clinicians - the immune parameters implicated could potentially be considered as predictive biomarkers of risk e.g. DR patients with longer duration of T1D may be susceptible for higher neutrophil to T-cell ratio, suggesting immunomodulation, thereby requiring closer follow-up.

Major strengths of this study include the homogeneity of the diabetic background (all T1D) and of patients in each diabetic stage (mNPDR, aPDR and iPDR), the use of an age-and gendermatched control group as well as the masking of the researchers evaluating blood samples with regards to clinical findings. The subgrouping of DR into mNPDR, aPDR and iPDR allowed the study of potential associations between leukocyte alterations and early DR and the initiation of the disease (healthy controls vs mNPDR) and late DR and potentially the progression to advanced stages (mNPDR vs aPDR). It also allowed an evaluation of the potential impact of treatment of aPDR on the circulatory immune system (aPDR vs iPDR). Limitations include the small sample size in each of the DR subgroups, the pilot cross-sectional study design due to unavailability of prior data required for power calculation and the recruitment of all participants from a single geographical location (Belfast, Northern Ireland). Our results need to be confirmed in large cohort studies.

\section{CONCLUSIONS}

Data presented in this pilot study supports the association of DR with increased innate immunity, reduced adaptive immunity and reduced APC antigen-presentation capacity. Reduced expression of CD66a and CD157 on CD4 ${ }^{+} \mathrm{T}$ cells were all observed in patients with DR. Data suggests that an altered systemic immune status could contribute to both DR development and progression. Furthermore, a longer duration of diabetes was associated with pathological changes in immune parameters including neutrophil/CD4 ${ }^{+} \mathrm{T}$-cell ratio and $\mathrm{CD}^{+} \mathrm{T}$-cell proportions. Large cohort multicenter studies will be needed to confirm the results and to further investigate the functional 
- Manuscript publication in Current Eye Research on $30^{\text {th }}$ Jan 2020

doi.org/10.1080/02713683.2020.1718165

alterations of immune cells in DR in order to understand the immune mechanisms and identify potential targets for immunotherapy.

\section{ABBREVIATIONS}

AGEs: advanced glycation end-products; ANOVA: analysis of variance; APCs: antigenpresenting cells; aPDR: active proliferative diabetic retinopathy; BMI: body mass index; BP: blood pressure; BRB: blood-retina-barrier; DR: diabetic retinopathy; EC: endothelial cell; EDTA: ethylenediaminetetraacetic acid; G-CSF: granulocyte colony-stimulating factor; iPDR: inactive proliferative diabetic retinopathy; LMR: lymphocyte-monocyte ratio; MHC-II: major histocompatibility complex, class II; mNPDR: mild non-proliferative diabetic retinopathy; NLR: neutrophil-lymphocyte ratio; NPDR: non-proliferative diabetic retinopathy; PDR: proliferative diabetic retinopathy; PRP: pan-retinal photocoagulation; SEM: standard error of the mean; SPSS: statistical package for the social sciences; T1D: type 1 diabetes; TCR: T-cell receptor; VEGF: vascular endothelial growth factor

\section{DECLARATIONS}

- The study was approved by the Office for Research Ethics Committees Northern Ireland (ORECNI, Ref: 14/NI/0084) and procedures were performed in accordance with the tenets of the Declaration of Helsinki on research into human volunteers. Written informed consent was obtained from all participants prior to their enrolment in this study.

- Some data have been presented in abstract/poster format at the Annual Meeting of the Association for Research in Vision and Ophthalmology (ARVO) 2017, 6-11 May, Baltimore, MD, USA (Poster A0040).

\section{CONSENT FOR PUBLICATION}

Not applicable 
- Manuscript publication in Current Eye Research on $30^{\text {th }}$ Jan 2020

doi.org/10.1080/02713683.2020.1718165

AVAILABILITY OF DATA AND MATERIALS

All data generated or analysed during this study are included in this published article.

\section{COMPETING INTERESTS}

The authors declare that they have no competing interests.

\section{FUNDING}

This work was supported by funding from Juvenile Diabetes Research Foundation (JDRF; Ref: 2SRA-2014-141-Q-R) and through the generous support of Miss Elizabeth Sloan.

\section{AUTHORS' CONTRIBUTIONS}

HX, NL and MC conceived the study. GO, HX and NL designed the experiments. GO conducted the experiments and acquired data. GO and DMW analysed the results. GO, HX, NL, MC, AL and JRH discussed and interpreted the data. NL, DA and NJ recruited patients. GO and HX drafted the manuscript and all authors reviewed the manuscript.

\section{ACKNOWLEDGEMENTS}

We thank the patients who participated in this study.

\section{REFERENCES}

1. Cheung N, Mitchell P, Wong TY. Diabetic retinopathy. Lancet. 2010;376(9735):124-36.

2. Wilkinson C, Ferris FL, Klein RE, Lee PP, Agardh CD, Davis M, et al. Proposed international clinical diabetic retinopathy and diabetic macular edema disease severity scales. Ophthalmology. 2003;110(9):1677-82.

3. Tang J, Kern TS. Inflammation in diabetic retinopathy. Prog Retin Eye Res. 2011;30(5):34358.

4. $\mathrm{Xu} \mathrm{H}$, Chen M, Forrester JV. Para-inflammation in the aging retina. Prog Retin Eye Res. 2009;28(5):348-68.

5. $\mathrm{Xu} \mathrm{H}$, Chen $\mathrm{M}$. Diabetic retinopathy and dysregulated innate immunity. Vision Res. 2017;139:39-46. 
- Manuscript publication in Current Eye Research on $30^{\text {th }}$ Jan 2020

doi.org/10.1080/02713683.2020.1718165

6. Crane IJ, Liversidge J. Mechanisms of leukocyte migration across the blood-retina barrier. Semin Immunopathol. 2008;30(2):165-77.

7. Zeng H, Green WR, Tso MO. Microglial activation in human diabetic retinopathy. Arch Ophthalmol. 2008;126(2):227-32.

8. Chibber R, Ben-Mahmud BM, Chibber S, Kohner EM. Leukocytes in diabetic retinopathy. Curr Diabetes Rev. 2007;3(1):3-14.

9. Atkinson MA, Eisenbarth GS, Michels AW. Type 1 diabetes. The Lancet. 2014;383(9911):69-82.

10. Huang J, Xiao Y, Xu A, Zhou Z. Neutrophils in type 1 diabetes. J Diabetes Investig. 2016;7(5):652-63.

11. Harsunen M, Puff R, D’Orlando O, Giannopoulou E, Lachmann L, Beyerlein A, et al. Reduced blood leukocyte and neutrophil numbers in the pathogenesis of type 1 diabetes. Horm Metab Res. 2013;45(06):467-70.

12. Orban T, Kis J, Szereday L, Engelmann P, Farkas K, Jalahej H, et al. Reduced CD4+ T-cellspecific gene expression in human type 1 diabetes mellitus. J Autoimmun. 2007;28(4):17787.

13. Gross JG, Glassman AR, Liu D, Sun JK, Antoszyk AN, Baker CW, et al. Five-year outcomes of panretinal photocoagulation vs intravitreous ranibizumab for proliferative diabetic retinopathy: a randomized clinical trial. JAMA Ophthalmol. 2018;136(10):1138-48.

14. Yau JW, Rogers SL, Kawasaki R, Lamoureux EL, Kowalski JW, Bek T, et al. Global prevalence and major risk factors of diabetic retinopathy. Diabetes Care. 2012;35(3):556-64.

15. Stitt AW, Lois N, Medina RJ, Adamson P, Curtis TM. Advances in our understanding of diabetic retinopathy. Clin Sci. 2013;125(1):1-17.

16. Anand-Apte B, Hollyfield JG. Developmental Anatomy of the Retinal and Choroidal Vasculature. In: Joseph CB, Dean B, editors. The Retina and Its Disorders. Oxford, UK: Academic Press; 2011. p. 179-85.

17. Joussen AM, Murata T, Tsujikawa A, Kirchhof B, Bursell S-E, Adamis AP. Leukocytemediated endothelial cell injury and death in the diabetic retina. Am $\mathrm{J}$ Pathol. 2001;158(1):147-52.

18. Barouch FC, Miyamoto K, Allport JR, Fujita K, Bursell S-E, Aiello LP, et al. Integrinmediated neutrophil adhesion and retinal leukostasis in diabetes. Invest Ophthalmol Vis Sci. 2000;41(5):1153-8.

19. Li Y, Smith D, Li Q, Sheibani N, Huang S, Kern T, et al. Antibody-mediated retinal pericyte injury: implications for diabetic retinopathy. Invest Ophthalmol Vis Sci. 2012;53(9):5520-6.

20. Zhang L, Li Y, Payne J, Srivastava S, Fan X, Fung J, et al. Presence of retinal pericytereactive autoantibodies in diabetic retinopathy patients. Sci Rep. 2016;6:20341. 
- Manuscript publication in Current Eye Research on $30^{\text {th }}$ Jan 2020 doi.org/10.1080/02713683.2020.1718165

21. McCourt M, Wang JH, Sookhai S, Redmond HP. Proinflammatory mediators stimulate neutrophil-directed angiogenesis. Arch Surg. 1999;134(12):1325-31.

22. Neagoe P-E, Brkovic A, Hajjar F, Sirois MG. Expression and release of angiopoietin-1 from human neutrophils: intracellular mechanisms. Growth Factors. 2009;27(6):335-44.

23. Mantovani A, Cassatella M, Costantini C, Jaillon S. Neutrophils in the activation and regulation of innate and adaptive immunity. Nat Rev Immunol. 2011;11(8):519-31.

24. Nagareddy PR, Murphy AJ, Stirzaker RA, Hu Y, Yu S, Miller RG, et al. Hyperglycemia promotes myelopoiesis and impairs the resolution of atherosclerosis. Cell Metab. 2013;17(5):695-708.

25. Vallerskog T, Martens GW, Kornfeld H. Diabetic mice display a delayed adaptive immune response to Mycobacterium tuberculosis. J Immunol. 2010;184(11):6275-82.

26. Shah BR, Hux JE. Quantifying the risk of infectious diseases for people with diabetes. Diabetes Care. 2003;26(2):510-3.

27. Casqueiro J, Alves C. Infections in patients with diabetes mellitus: A review of pathogenesis. Indian J Endocrinol Metab. 2012;16(Suppl1):S27-36.

28. Bajaña S, Herrera-González N, Narváez J, Torres-Aguilar H, Rivas-Carvalho A, Aguilar SR, et al. Differential CD4+ T-cell memory responses induced by two subsets of human monocyte-derived dendritic cells. Immunology. 2007;122(3):381-93.

29. Steinbach F, Henke F, Krause B, Thiele B, Burmester G-R, Hiepe F. Monocytes from systemic lupus erythematous patients are severely altered in phenotype and lineage flexibility. Ann Rheum Dis. 2000;59(4):283-8.

30. Drewry AM, Ablordeppey EA, Murray ET, Beiter ER, Walton AH, Hall MW, et al. Comparison of monocyte human leukocyte antigen-DR expression and stimulated tumor necrosis factor alpha production as outcome predictors in severe sepsis: a prospective observational study. Crit Care. 2016;20(1):334.

31. Nagaishi T, Chen Z, Chen L, Iijima H, Nakajima A, Blumberg R. CEACAM1 and the regulation of mucosal inflammation. Mucosal Immunol. 2008;1:S39-42.

32. DeAngelis AM, Heinrich G, Dai T, Bowman TA, Patel PR, Lee SJ, et al. Carcinoembryonic Antigen-Related Cell Adhesion Molecule 1. Diabetes. 2008;57(9):2296-303.

33. Ludewig P, Flachsbarth K, Wegscheid C, Tiegs G, Richard G, Wagener C, et al. CEACAM1 Confers Resistance Toward Oxygen-Induced Vessel Damage in a Mouse Model of Retinopathy of PrematurityRole of CEACAM1 in Retinal Neovascularization. Invest Ophthalmol Vis Sci. 2014;55(12):7950-60.

34. Quarona V, Zaccarello G, Chillemi A, Brunetti E, Singh VK, Ferrero E, et al. CD38 and CD157: a long journey from activation markers to multifunctional molecules. Cytometry B Clin Cytom. 2013;84(4):207-17.

35. Itoh M, Ishihara K, Hiroi T, Lee BO, Maeda H, Iijima H, et al. Deletion of bone marrow stromal cell antigen-1 (CD157) gene impaired systemic thymus independent-2 antigen- 
- Manuscript publication in Current Eye Research on $30^{\text {th }}$ Jan 2020 doi.org/10.1080/02713683.2020.1718165

induced IgG3 and mucosal TD antigen-elicited $\operatorname{IgA}$ responses. $\mathrm{J}$ Immunol. 1998;161(8):3974-83. 
- Manuscript publication in Current Eye Research on $30^{\text {th }}$ Jan 2020 doi.org/10.1080/02713683.2020.1718165

\section{Figures and legends}

Figure 1: Gating strategies used in flow cytometry analyses to identify subsets of circulating leukocytes. Representative image showing (A) Forward-scatter area (FSC-A) vs side-scatter area (SSC-A) plot used to exclude debris and the gated population was then plotted as (B) FSC-A vs SSC-A plot revealing three leukocyte subsets: lymphocytes, monocytes and granulocytes; Representative data of (C) HLA-DR vs CD16 showing CD16 ${ }^{\text {hi HLA-DR }}$ - neutrophils; (D) CD4 vs CD8 showing $\mathrm{CD}^{+}$and $\mathrm{CD}^{+}{ }^{+}$-lymphocytes; (E) CD56 vs CD19 showing CD56 ${ }^{+}$natural killer cells and CD19 ${ }^{+}$B cells; (F) HLA-DR vs SSC-A showing HLA-DR ${ }^{+}$cells and (G) CD14 vs SSCA showing $\mathrm{CD} 14^{+}$cells. Monocytes were identified by plotting $(\mathrm{H}) \mathrm{CD} 14$ vs CD16 to exclude CD16 ${ }^{-}$and $\mathrm{CD}^{-} 4^{-}$cells. The gated population was then plotted as (I) HLA-DR vs CD16 to exclude CD16 ${ }^{+} \mathrm{HLA}^{-\mathrm{DR}^{-}}$cells and show monocytes. The gated population was then plotted as (J) CD14 vs CD16 showing true monocyte population comprising of three subsets: $\mathrm{CD} 14^{+} \mathrm{CD} 16^{-}$(Classical monocytes), $\mathrm{CD}_{14}{ }^{+} \mathrm{CD} 16^{+}$(Intermediate monocytes) and $\mathrm{CD} 14^{-} \mathrm{CD} 16^{+}$(non-classical monocytes). Leukocyte subsets and gate frequencies in plots $(\mathrm{C}-\mathrm{H}),(\mathrm{I})$ and $(\mathrm{J})$ were based on plots (B), (H) and (I) respectively.
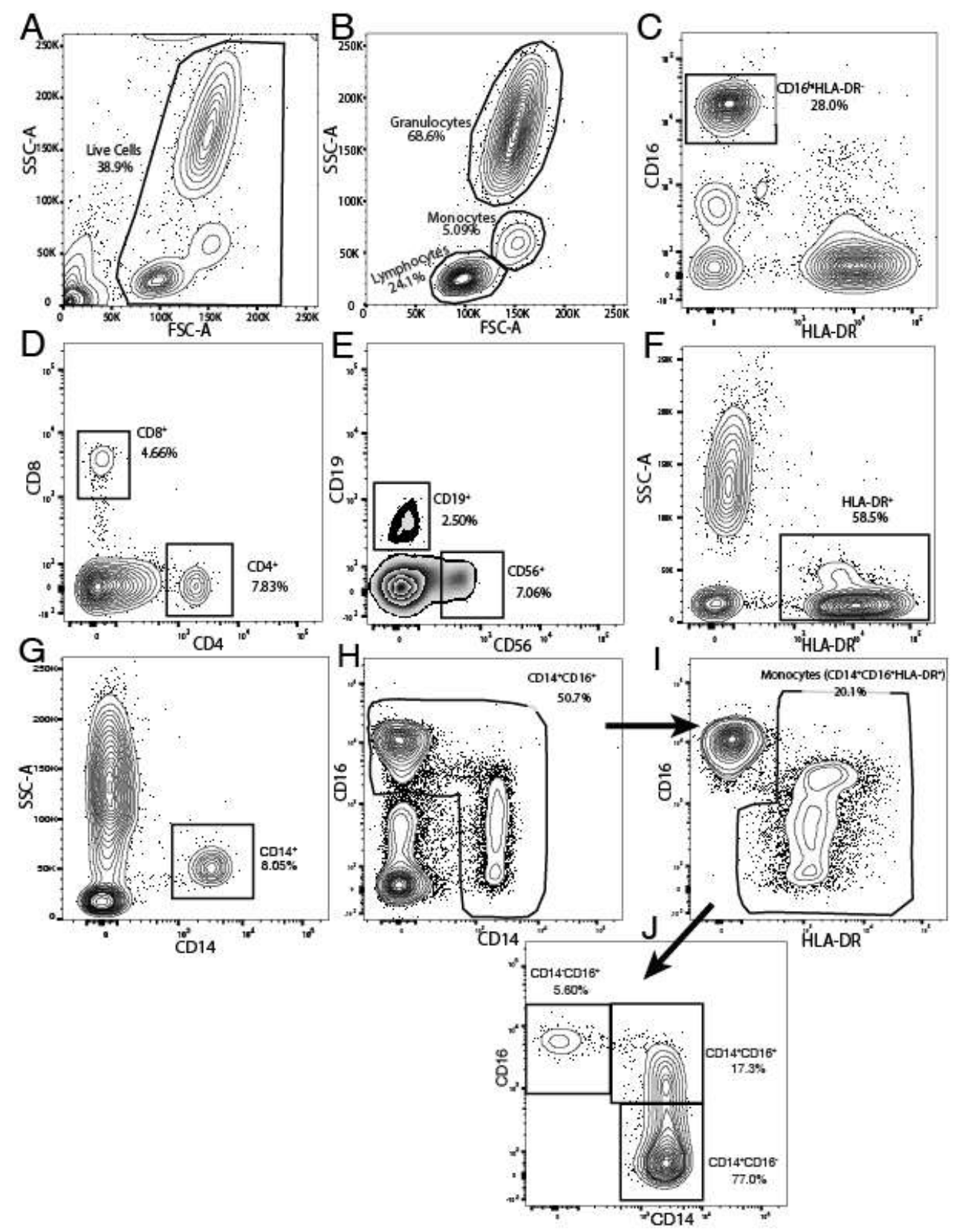
- Manuscript publication in Current Eye Research on $30^{\text {th }}$ Jan 2020 doi.org/10.1080/02713683.2020.1718165

Figure 2: Characterization of innate immune cells, including neutrophils, monocytes, HLA-DR and other surface marker characteristics in DR patients and healthy controls. (A-D) The percentages of total leukocytes that are: (A) CD16 ${ }^{\text {hi }} \mathrm{HLA}^{-} \mathrm{DR}^{-}$neutrophils; (B) HLA-DR ${ }^{+}$; (C) $\mathrm{CD}^{+} 6^{+}$and (D) Monocytes. (E-F) The percentages of monocytes that are: (E) Non-classical monocytes (CD14-CD16 ${ }^{+}$; (F) Classical monocytes $\left(\mathrm{CD} 14^{+} \mathrm{CD} 16^{-}\right)$and $(\mathrm{G})$ Intermediate monocytes $\left(\mathrm{CD} 14^{+} \mathrm{CD} 16^{+}\right)$. $(\mathrm{H}-\mathrm{M})$ The average expression level of: CCR2 on (H) CD16 ${ }^{\text {hi } H L A-~}$ $\mathrm{DR}^{-}$neutrophils and (I) Monocytes; CCR5 on (J) CD16 ${ }^{\text {hi HLA-DR }}{ }^{-}$neutrophils and (K) Monocytes; CD62L on (L) CD16 ${ }^{\text {hi }}$ HLA-DR ${ }^{-}$neutrophils and (M) Monocytes. Results are presented as mean \pm SEM. $n=13$ for healthy and 39 for DR. ${ }^{*} P<0.05$ in Independent samples $T$ test.

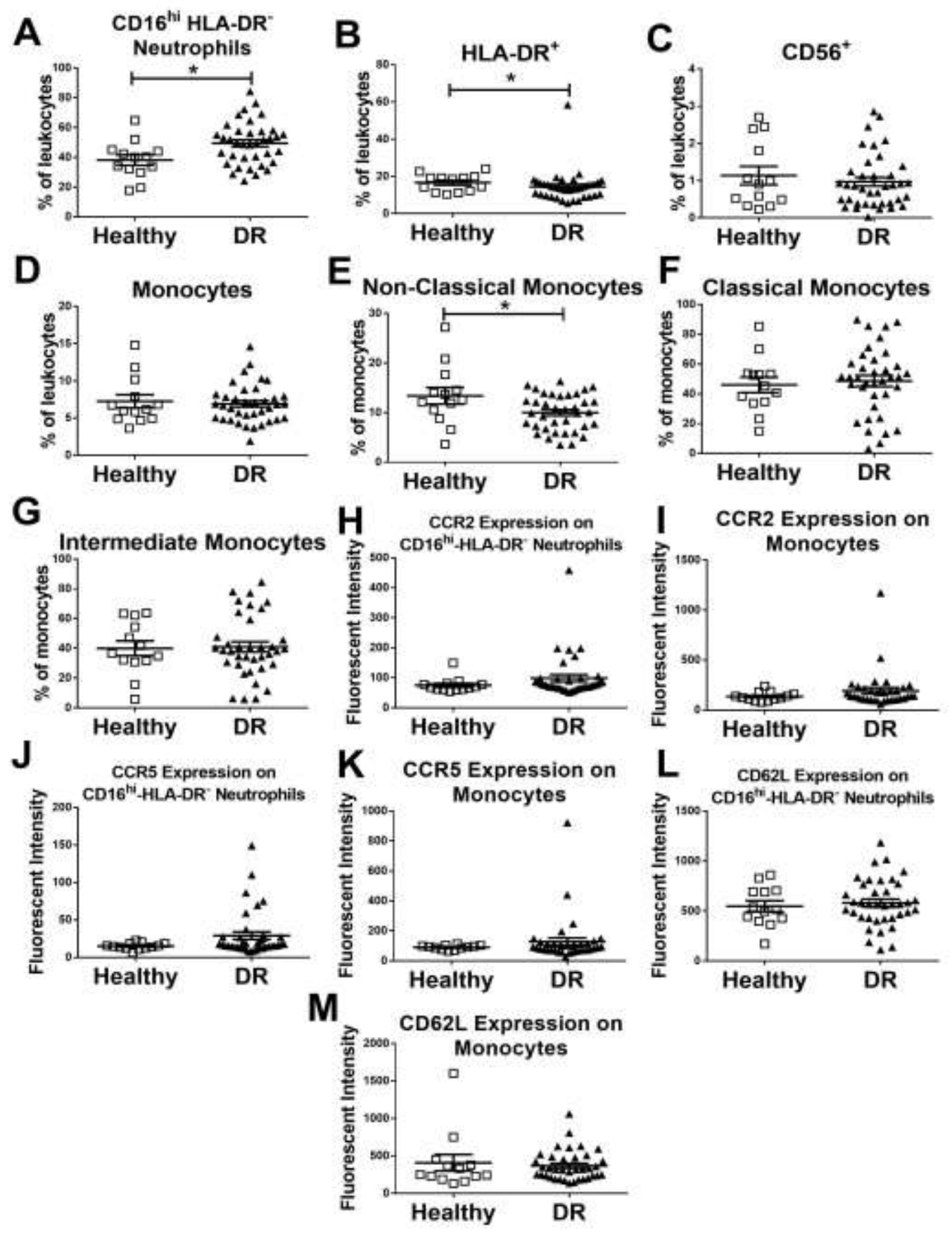


- Manuscript publication in Current Eye Research on $30^{\text {th }}$ Jan 2020 doi.org/10.1080/02713683.2020.1718165

Figure 3: Characterization of adaptive immune cells, including lymphocytes, CD66a and CD157 in DR patients and healthy controls. (A-D) The percentages of total leukocytes that are: (A) Total lymphocytes; (B) $\mathrm{CD}^{+}$T-cells; (C) $\mathrm{CD} 8^{+} \mathrm{T}$-cells and (D) $\mathrm{CD} 19^{+} \mathrm{B}$-cells. (E-G) The average expression level of: (E) CD66a (CEACAM1); (F) CD157 (BST1) and (G) CD305 (LAIR1) on $\mathrm{CD}^{+}$T-cells. Results are presented as mean \pm SEM. $n=13$ for healthy and 39 for DR. $* P<0.05$, $* * P<0.01, * * * P<0.001$ in Independent samples $T$-test.

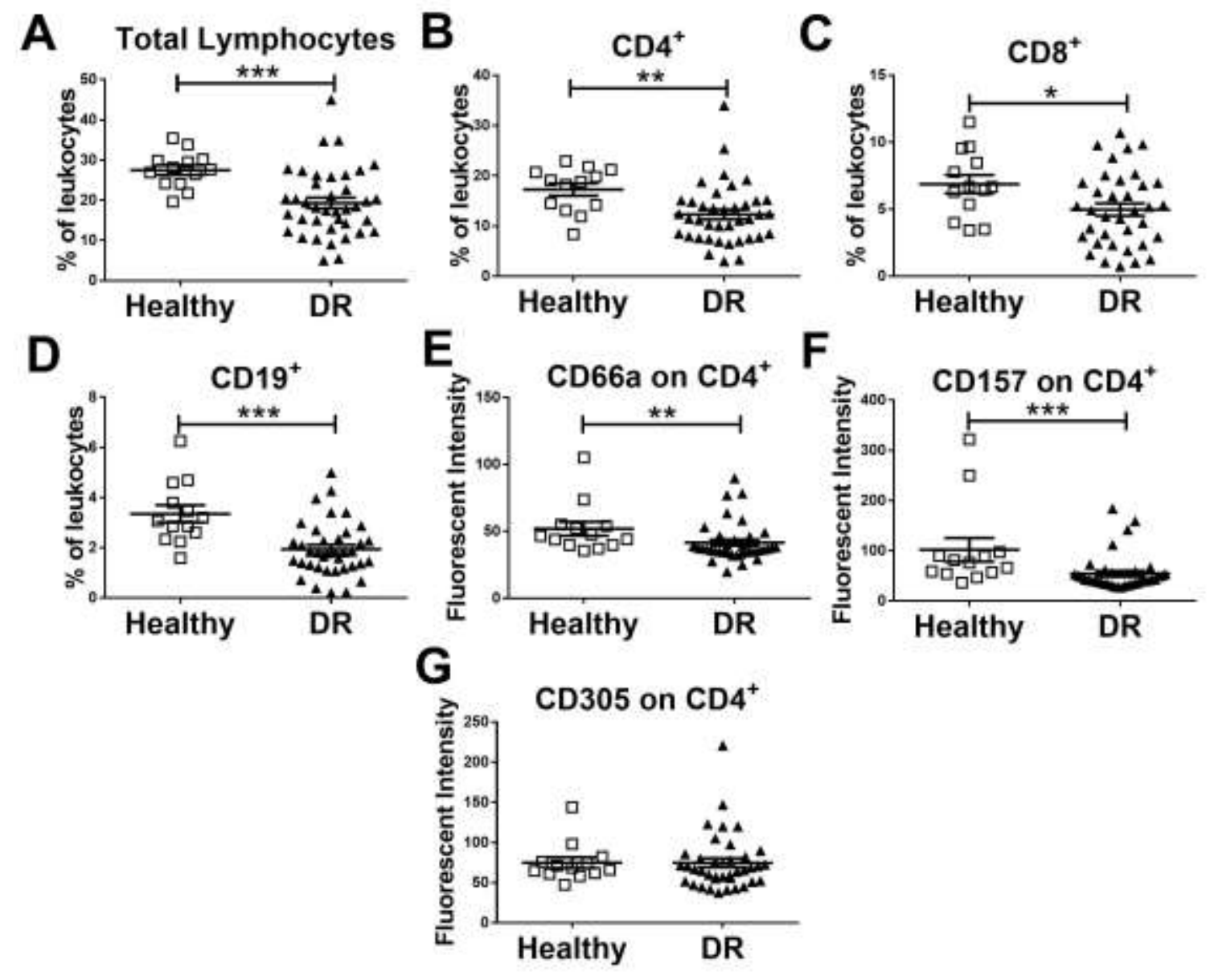


- Manuscript publication in Current Eye Research on $30^{\text {th }}$ Jan 2020 doi.org/10.1080/02713683.2020.1718165

Figure 4: Characterization of immune cell ratios in DR patients and healthy controls. (A) Neutrophil-lymphocyte ratio; (B) CD16 ${ }^{\text {hi }} \mathrm{HLA}^{-D R^{-}}$neutrophils/T-cell ratio; (C) CD16 ${ }^{\text {hi }} \mathrm{HLA}^{-} \mathrm{DR}^{-}$ neutrophils/CD4 ${ }^{+}$T-cell ratio; (D) $\mathrm{CD} 16^{\mathrm{hi}} \mathrm{HLA}^{-} \mathrm{DR}^{-}$neutrophils/CD8 ${ }^{+}$T-cell ratio; (E) CD16 ${ }^{\text {hi }}$ HLA-DR ${ }^{-}$neutrophils/CD19+ B-cell ratio; (F) CD16 ${ }^{\text {hi }}$ HLA-DR $^{-}$neutrophils/monocyte ratio $(\mathrm{G})$ Lymphocyte-monocyte ratio and $(\mathrm{H}) \mathrm{T}$-cell/CD14 ${ }^{+}$ratio. Results are presented as mean \pm SEM. $n=13$ for healthy and 39 for DR. $* P<0.05, * * P<0.01, * * * P<0.001$ in Independent samples $T$-test.

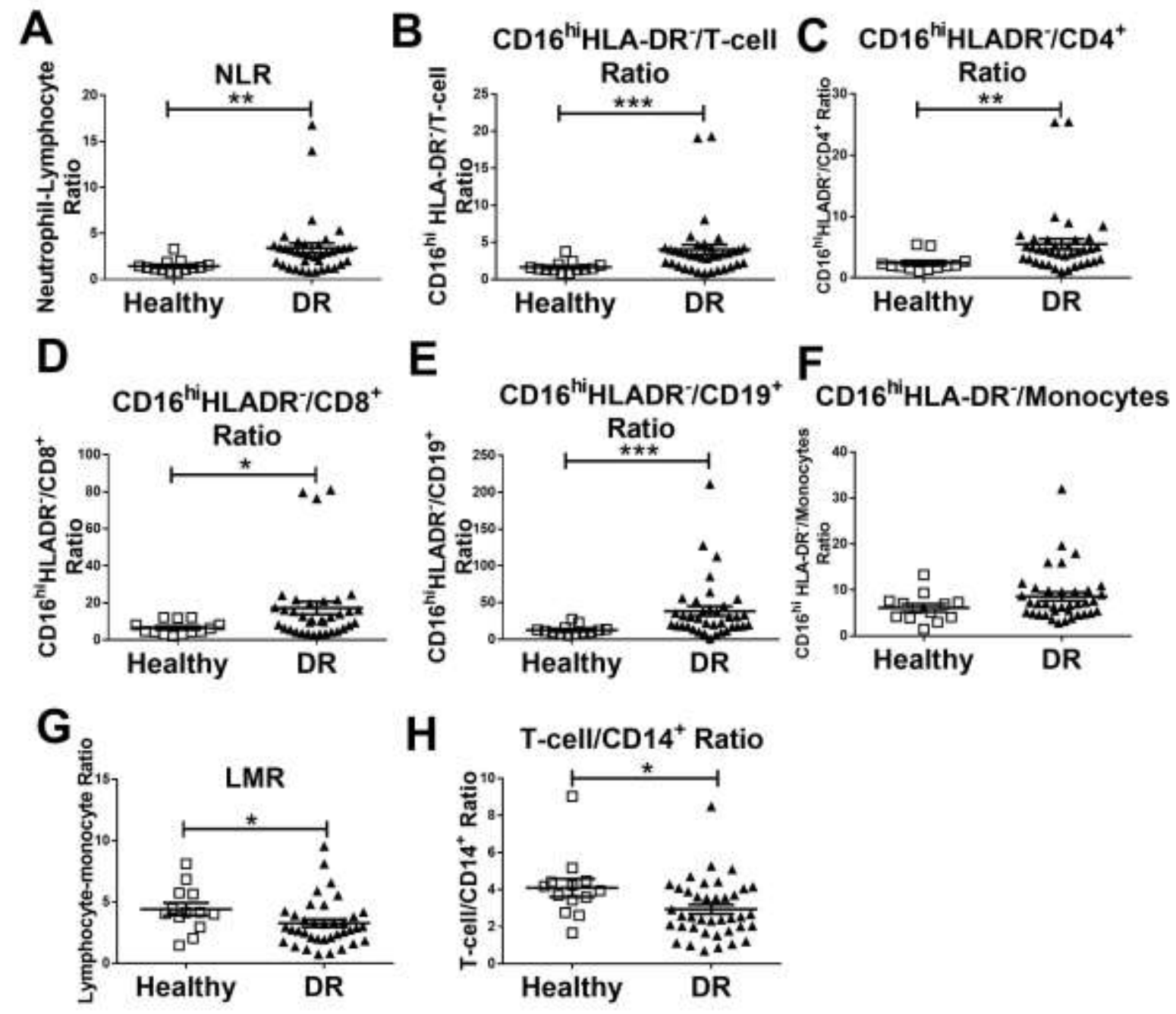


- Manuscript publication in Current Eye Research on $30^{\text {th }}$ Jan 2020 doi.org/10.1080/02713683.2020.1718165

Figure 5: The relationship between duration of type-1 diabetes (T1D) and systemic immunophenotype of DR patients. (A-I) Correlation of T1D duration against: (A) CD8 ${ }^{+} \mathrm{T}$-cells; (B) T-cell/CD14 ${ }^{+}$ratio; (C) CD16 ${ }^{\text {hi }}$ HLA-DR $^{-}$neutrophils/T-cell ratio; (D) CD16 ${ }^{\text {hi HLA-DR }}{ }^{-}$ neutrophils/CD4 ${ }^{+}$T-cell ratio; (E) $\mathrm{CD} 6^{\mathrm{hi}} \mathrm{HLA} \mathrm{DR}^{-}$neutrophils/CD8 ${ }^{+}$T-cell ratio; (F) CD16 ${ }^{\text {hi HLA-DR }}{ }^{-}$neutrophils; (G) Total lymphocytes; (H) CD4 ${ }^{+}$T-cells and (I) CD19 ${ }^{+}$B-cells. Regression line, significance levels $(p)$, coefficient of determination $\left(\mathrm{R}^{2}\right)$ and regression equation $(y=a+b x)$ are shown on each graph. $n=39-41$. Linear regression.
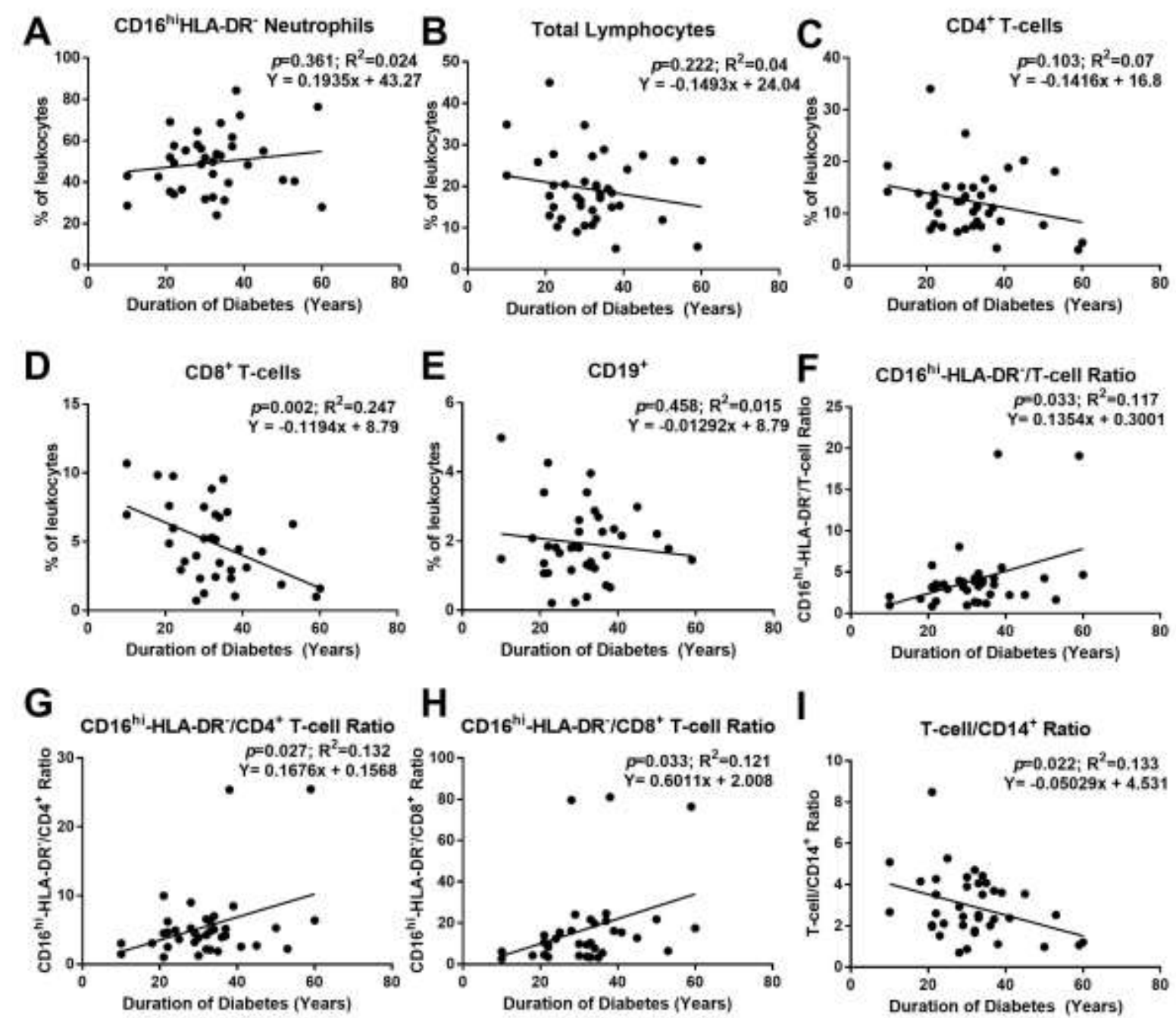
- Manuscript publication in Current Eye Research on $30^{\text {th }}$ Jan 2020 doi.org/10.1080/02713683.2020.1718165

Figure 6: Changes in populations of adaptive and neutrophilic immune cells respectively with DR progression. (A-E) The percentages of total leukocytes that are: (A) Total lymphocytes; (B) CD4 T-cells; (C) $\mathrm{CD}^{+}$T-cells; (D) $\mathrm{CD}^{+} 9^{+}$B-cells and (E) CD16 ${ }^{\text {hi }} \mathrm{HLA}^{-D R^{-}}$neutrophils. (F) Neutrophil-lymphocyte ratio and (G) CD16 ${ }^{\text {hi HLA-DR }}{ }^{-}$neutrophils/CD4 ${ }^{+}$T-cell ratio. Results are presented as mean \pm SEM. $n=12-14$ per group. ${ }^{*} P<0.05,{ }^{* *} P<0.01$ in Independent samples $T$ test.

\section{A Total Lymphocytes}

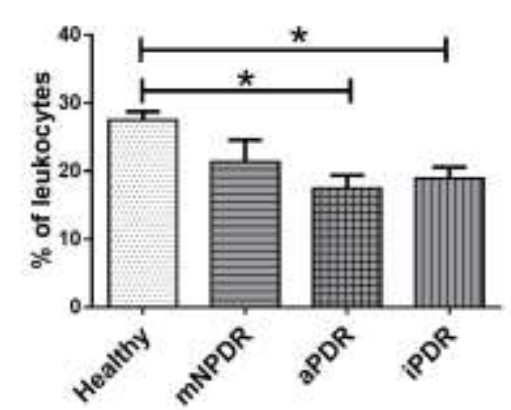

D

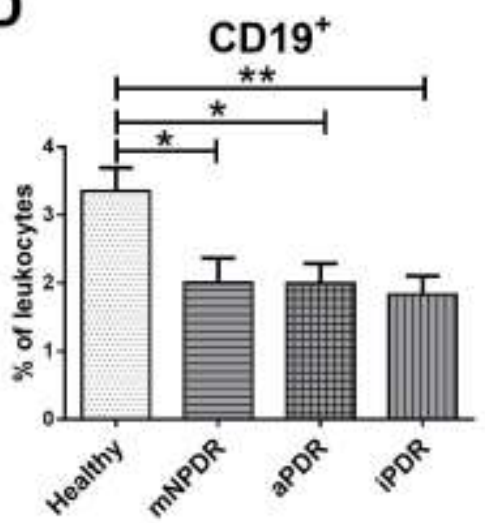

B

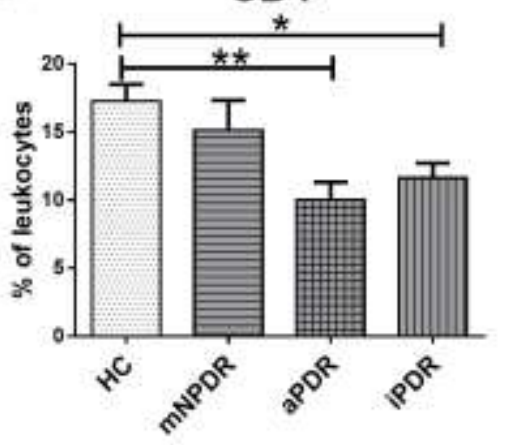

E
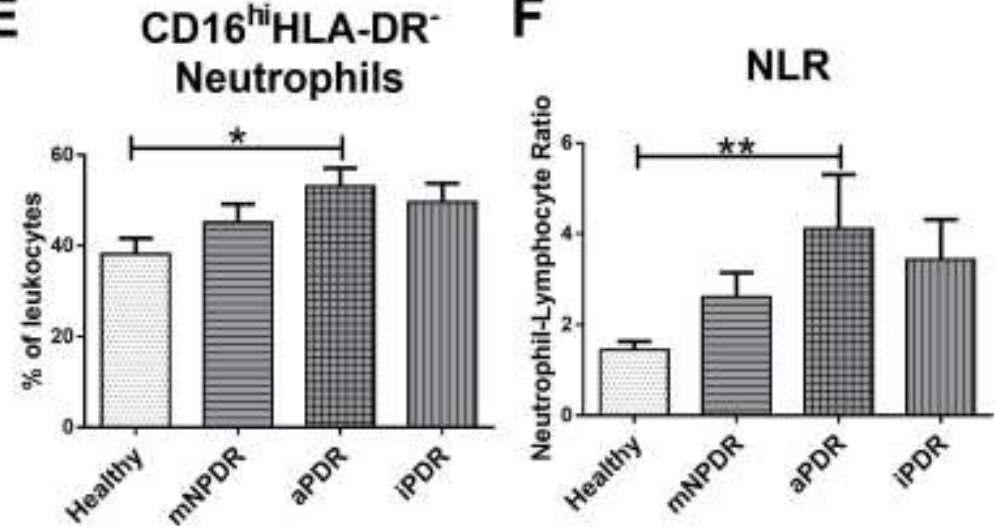

\section{G CD16 $^{\text {hi }}$ HLADR $^{*} / \mathrm{CD}^{+}$ Ratio}

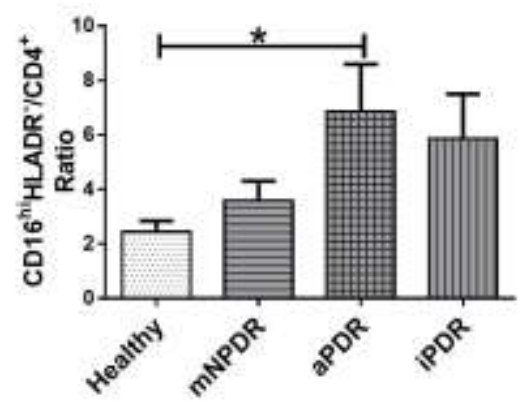


- Manuscript publication in Current Eye Research on $30^{\text {th }}$ Jan 2020 doi.org/10.1080/02713683.2020.1718165

Table 1: Antibodies used for flow cytometry

\begin{tabular}{|c|c|c|c|c|c|}
\hline Antigen & Clone & Conjugate & Dilution & Company & Catalogue \\
\hline CD4 & RPA-T4 & PB & $1: 40$ & \multirow{12}{*}{$\begin{array}{c}\text { BD- } \\
\text { Biosciences }\end{array}$} & 558116 \\
\hline CD4 & RPA-T4 & $\begin{array}{l}\text { PerCp- } \\
\text { Cy5.5 }\end{array}$ & $1: 40$ & & 560650 \\
\hline CD8 & RPA-T8 & PE-Cy7 & $1: 40$ & & 557746 \\
\hline CD19 & HIB19 & FITC & $1: 10$ & & 555412 \\
\hline CD56 & B159 & PE & $1: 10$ & & 555516 \\
\hline CD14 & $\mathrm{M} \varphi \mathrm{P} 9$ & APC-Cy7 & $1: 40$ & & 557831 \\
\hline CD16 & $3 \mathrm{G} 8$ & PB & $1: 40$ & & 558122 \\
\hline CD11b & ICRF44 & $\mathrm{PE}$ & $1: 40$ & & 555388 \\
\hline CCR5 & 2D7/CCR5 & PE-Cy7 & $1: 20$ & & 557752 \\
\hline CD157 & SY/11B5 & BV421 & $1: 40$ & & 564869 \\
\hline CD62L & Dreg56 & APC & $1: 14.3$ & & 559772 \\
\hline CD305 & DX26 & BB515 & $1: 40$ & & 565153 \\
\hline CCR2 & TG5/CCR2 & $\begin{array}{l}\text { PerCp- } \\
\text { Cy5.5 }\end{array}$ & $1: 40$ & Biolegend & 335303 \\
\hline $\begin{array}{l}\text { HLA- } \\
\text { DR }\end{array}$ & L243 & $\mathrm{PE}$ & $1: 40$ & eBioscience & $9012-9952-120$ \\
\hline CD66a & 283340 & APC & $1: 20$ & $\begin{array}{c}\text { R\&D } \\
\text { Systems }\end{array}$ & FAB2244A \\
\hline
\end{tabular}


- Manuscript publication in Current Eye Research on $30^{\text {th }}$ Jan 2020 doi.org/10.1080/02713683.2020.1718165

Table 2: Demographics and clinical characteristics of study participant

\begin{tabular}{|c|c|c|c|c|c|c|c|}
\hline \multirow[b]{2}{*}{ Participants characteristics } & \multirow{2}{*}{$\begin{array}{l}\begin{array}{l}\text { All } \\
(n=54 ;\end{array} \\
100 \%)\end{array}$} & \multirow{2}{*}{$\begin{array}{l}\text { HC } \quad(n=13 ; \\
24.1 \%)\end{array}$} & \multirow{2}{*}{$\begin{array}{c}\text { DR } \\
(n=41 ; 75.9 \%)\end{array}$} & \multicolumn{3}{|c|}{ DR Subtypes } & \multirow{2}{*}{$\begin{array}{l}P \text { values } \\
H C \text { vs DR }\end{array}$} \\
\hline & & & & $\begin{array}{l}\text { mNPDR } \quad(n=13 \\
24.1 \%)\end{array}$ & $\begin{array}{l}\text { iPDR } \quad(n=14 ; \\
25.9 \%)\end{array}$ & $\begin{array}{l}\text { aPDR } \quad(n=14 \\
25.9 \%)\end{array}$ & \\
\hline Age $($ mean \pm SD $)$, years & $47 \pm 11.7$ & $44.5 \pm 9.6$ & $47.8 \pm 12.27$ & $47.8 \pm 9.2$ & $41.9 \pm 12.5$ & $53.6 \pm 12.4$ & $0.385^{*}$ \\
\hline Female (No. (\%)) & $16(29.6)$ & $4(30.8)$ & $12(22.2)$ & $4(30.8)$ & $5(35.7)$ & $3(21.4)$ & $0.918^{\dagger}$ \\
\hline Duration of T1D $($ mean $\pm S D)$, years & $24.1 \pm 16.8$ & N/A & $31.75 \pm 11.25$ & $28.9 \pm 8$ & $30.3 \pm 13.2$ & $35.9 \pm 11.2$ & N/A \\
\hline Family history of T1D (No. (\%)) & $31(57.4)$ & $8(61.5)$ & $23(42.6)$ & $8(61.5)$ & $8(57.1)$ & $7(50)$ & $0.73^{\dagger}$ \\
\hline $\begin{array}{l}\text { Age at T1D diagnosis (mean } \pm \text { SD), } \\
\text { years }\end{array}$ & $16.3 \pm 8.72$ & N/A & $16.3 \pm 8.72$ & $19 \pm 8.6$ & $12.3 \pm 8.2$ & $17.7 \pm 8.5$ & N/A \\
\hline Duration of Insulin use (mean \pm SD) & $23.6 \pm 16.7$ & N/A & $31.15 \pm 11.51$ & $28.8 \pm 7.8$ & $28.6 \pm 13.8$ & $35.8 \pm 11.1$ & N/A \\
\hline $\begin{array}{l}\text { Time of blood collection (mean } \pm \text { SD, } \\
\text { hours }\end{array}$ & $13 \pm 2.6$ & $12.6 \pm 3.2$ & $13.2 \pm 2.34$ & $13.9 \pm 2.4$ & $12.6 \pm 2.1$ & $13 \pm 2.6$ & $0.552^{*}$ \\
\hline Systolic BP (mean \pm SD), mmHG & $131.7 \pm 17.5$ & $130.77 \pm 17$ & $132 \pm 17.9$ & $131.7 \pm 18.6$ & $128.6 \pm 19$ & $135.6 \pm 16.7$ & $0.828^{*}$ \\
\hline Diastolic BP (mean \pm SD), mmHG & $76.85 \pm 11.4$ & $77 \pm 10.8$ & $76.8 \pm 11.67$ & $74.9 \pm 11.3$ & $75.4 \pm 12.3$ & $80 \pm 11.6$ & $0.958^{*}$ \\
\hline BMI $(\operatorname{mean} \pm$ SD $)$ & $29.5 \pm 6.0$ & $28.5 \pm 7.5$ & $29.85 \pm 5.44$ & $29.7 \pm 4.2$ & $28.7 \pm 5.5$ & $31.1 \pm 6.4$ & $0.495^{*}$ \\
\hline $\begin{array}{l}\text { Have other diabetic complications } \\
(\text { No. }(\%))\end{array}$ & $11(20.4)$ & N/A & $11(20.4)$ & $2(15.4)$ & $3(21.4)$ & $6(42.9)$ & N/A \\
\hline $\begin{array}{l}\text { History of macrovascular disease } \\
\text { (No. }(\%))\end{array}$ & $8(14.8)$ & N/A & $8(14.8)$ & $1(7.7)$ & $2(14.3)$ & $5(35.7)$ & N/A \\
\hline Smoking history & & & & & & & $0.071^{\dagger}$ \\
\hline Non-smoker (No. (\%)) & $30(55.6)$ & $7(53.8)$ & $23(42.6)$ & $7(53.8)$ & $7(50)$ & $9(64.3)$ & \\
\hline Former smoker (No. (\%)) & $20(37)$ & $3(23.1)$ & $17(31.5)$ & $6(46.2)$ & $7(50)$ & $4(28.6)$ & \\
\hline Current tobacco smoker (No. (\%)) & $3(5.6)$ & $2(15.4)$ & $1(1.9)$ & $0(0)$ & $0(0)$ & $1(7.1)$ & \\
\hline Current e-cigarette smoker (No. (\%)) & $1(1.9)$ & $1(7.7)$ & $0(0)$ & $0(0)$ & $0(0)$ & $0(0)$ & \\
\hline History of hypertension (No., (\%)) & $13(24.1)$ & N/A & $13(24.1)$ & $3(23.1)$ & $3(21.4)$ & $7(50)$ & N/A \\
\hline Duration of hypertension & & & & & & & $0.143^{\dagger}$ \\
\hline $\operatorname{Never}(\operatorname{No} .(\%))$ & $41(75.9)$ & $13(100)$ & $28(51.9)$ & $10(76.9)$ & $11(78.6)$ & $7(50)$ & \\
\hline$<5$ years $($ No. $(\%))$ & $4(7.4)$ & $0(0)$ & $4(7.4)$ & $1(7.7)$ & $1(7.1)$ & $2(14.3)$ & \\
\hline 5-10 years $($ No. $(\%))$ & $8(14.8)$ & $0(0)$ & $8(14.8)$ & $1(7.7)$ & $2(14.3)$ & $5(35.7)$ & \\
\hline$>10$ years $($ No. $(\%))$ & $1(1.9)$ & $0(0)$ & $1(1.9)$ & $1(7.7)$ & $0(0)$ & $0(0)$ & \\
\hline
\end{tabular}

${ }^{*}$ Independent samples t-test; ${ }^{\dagger}$ Pearson's chi-square test; SD Standard deviation; N/A Not applicable; HC - healthy control; DR - diabetic retinopathy; mPCR - mild non-proliferative DR, aPCR - active PCR, iPCR - inactive PDR 
- Manuscript publication in Current Eye Research on $30^{\text {th }}$ Jan 2020 doi.org/10.1080/02713683.2020.1718165 